\title{
Diversity of Alkane Hydroxylase Systems in the Environment
}

\author{
J.B. van Beilen ${ }^{1 *}$, Z. Li ${ }^{1}$, W.A. Duet ${ }^{1}$, \\ T.H.M. Smits ${ }^{1,2}$ and B. W itholt ${ }^{1}$ \\ 1 Institute of Biotechnology, ETH-Hönggerberg, $\mathrm{CH}-8093$ Zürich - Switzerland \\ 2 EN AC/ ISTE/ LBE, EPFL, CH-1015 Lausanne - Switzerland \\ e-mail: vanbeilen@biotech.biol.ethz.ch \\ * author for correspondence
}

\begin{abstract}
Résumé - Diversité des systèmes alcane hydroxylase dans l'environnement — La première étape dans la dégradation aérobie des alcanes par les bactéries, les levures et les champignons est catalysée par des oxygénases, une classe d'enzymes capables d'introduire des atomes d'oxygène issus de l'oxygène moléculaire dans le substrat alcane. Ces enzymes jouent un rôle important dans la biodégradation du pétrole et dans la biodégradation cométabolique de composés tels que le trichloroéthylène et les étherscarburants. De plus, ce sont des biocatalyseurs très utiles qui peuvent également servir de modèles pour caractériser une réaction chimique difficile : l'activation régio- et stéréospécifique de la liaison C-H. Plusieurs autres classes d'enzymes catalysent l'oxydation des alcanes. Les souches de levures capables de dégrader les alcanes contiennent plusieurs alcanes hydroxylases appartenant à la superfamille des $\mathrm{P} 450$, alors que différentes bactéries contiennent des enzymes similaires au système alcane hydroxylase membranaire de Pseudomonas putida GPo1. Les alcanes à courte chaîne sont probablement oxydés par des alcanes hydroxylases solubles similaires aux méthanes monooxygénases. La présence dans l'environnement de ces oxygénases a été étudiée dans des échantillons de sols et aquifères uniquement pour les alcanes hydroxylases associés aux membranes.
\end{abstract}

\begin{abstract}
Diversity of Alkane Hydroxylase Systems in the Environment - The first step in the aerobic degradation of alkanes by bacteria, yeasts, and fungi is catalyzed by oxygenases. These enzymes, which introduce oxygen atoms derived from molecular oxygen into the alkane substrate, play an important role in oil bioremediation and in the cometabolic degradation of compounds such as trichloroethylene and fuel oxygenates. In addition, they are useful biocatalysts and important models for a difficult chemical reaction: the regio- and stereospecific activation of $C-H$ bonds. Several unrelated enzyme classes catalyze the oxidation of alkanes. Alkane-degrading yeast strains contain multiple alkane hydroxylases belonging to the P450 superfamily, while many bacteria contain enzymes related to the Pseudomonas putida GPol membrane-bound alkane hydroxylase system. Short-chain alkanes are probably oxidized by alkane hydroxylases related to the soluble and particulate methane monooxygenases. Only the membrane-bound enzymes have been studied with respect to their prevalence in environments such as soils or aquifers.
\end{abstract}




\section{IN TRO DUCTIO N}

Saturated hydrocarbons such as linear, branched, and cyclic alkanes are highly reduced forms of carbon that are produced by geochemical processes from decaying plant and algal material. Alkanes constitute about $20-50 \%$ of crude oil, depending on the source of the oil. In addition, alkanes (predominantly long-chain compounds) are produced throughout the biosphere by living organisms (plants, algae and bacteria) as a waste product, a structural element, a defense mechanism, or as a chemoattractant. The assimilation of biogenic alkanes is a major process in geochemical terms, but has not been quantified. Recycling of alkanes from natural oil seepage, oil-spills and runoff due to countless dispersed sources has been estimated to amount to several million tons per year [1,2].

The microbial biodegradability of alkanes by microorganisms is well established. Almost a century ago, Söhngen was able to isolate bacteria that degrade methane [3] and longer alkanes [4]. Later in the 20th century, alkanes were considered for use as a feedstock for the production of single cell protein. This led to a flood of research in the fifties and sixties, which ended abruptly in response to the oil-crisis in 1973. Alkane-degrading microbes were also investigated by the oil industry for many other purposes, such as petroleum exploration (the presence of alkane degraders was thought to indicate the presence of oil- or gas fields), the treatment of environmental pollution, deparaffinization of jetfuel and diesel oil to reduce viscosity, microbially enhanced oil recovery, and because of corrosion of fuel lines or oil tanks due to bacteria able to grow on oil or petroleum (see for example [5-7], and references therein). More recently, alkane hydroxylase genes received increasing attention as markers to predict the potential of different environments for oil degradation (see references in Table 2). An emerging theme is the cometabolic degradation of recalcitrant chemicals such as methyl tert-butyl ether (MTBE) or trichloroethylene (TCE) by bacterial strains growing on short-chain alkanes $[8,9]$. Methane oxidation has often been regarded as a special case of alkane utilization, and was treated separately [10]. However, it now appears that at least some of the enzymes that are involved in the degradation of short-chain alkanes are very similar to methane monooxygenases [11]. Therefore, some information on these enzymes is included in this review. For a more detailed overview on the molecular biology and biochemistry of methane monooxygenases see Murrell et al. [12].

Alkanes are also known as paraffins (which can be translated as "not enough affinity") as they are chemically quite inert [13]. For biodegradation, the alkane molecules have to be activated to allow further metabolic steps. In the absence of oxygen, this is done by the addition of a $\mathrm{C}_{1}\left(\mathrm{CO}_{2}\right)$ or a $\mathrm{C}_{4}$ (fumarate) compound [14]. If oxygen is available, the initial activation step is carried out by oxygenases: enzymes that introduce oxygen atoms derived from molecular oxygen in the alkane substrate [15]. As the regio- and stereoselective oxidation of nonactivated methyl or methylene-group is a difficult but important chemical reaction, alkane hydroxylases are also studied as model systems for biomimetic catalysts [13]. From a biotechnological perspective, alkane hydroxylases are versatile biocatalysts, which carry out a wide range of useful oxidation reactions $[16,17]$. This review summarizes current knowledge on the diversity of alkane hydroxylase systems, their occurence in the environment, and their applications in biocatalysis and bioremediation.

\section{AERO BIC ALKANE DEGRADATION PATHW AYS}

Many microbial genera include strains that are able to grow on alkanes. Table 1 lists a small selection of genera that include strains from which genes involved in alkane degradation were cloned, or genera that are often mentioned in alkane degradation studies. Alkanes are usually activated by terminal oxidation to the corresponding primary alcohol, which is further oxidized by alcohol and aldehyde dehydrogenases. The resulting fatty acids enter the $\beta$-oxidation cycle (for general reviews see $[6,10,18]$ ). Shortchain alkanes are metabolized via terminal as well as subterminal oxidation [19], and many methanotrophs cooxidize short-chain alkanes at terminal as well as subterminal positions [7, 20]. Subterminal oxidation has also been detected for longer alkanes, e.g. in Penicillium, Bacillus, Pseudomonas [10], and more recently in Rhodococcus sp. Q15 [21]. The secondary alcohols are converted to the corresponding ketone [22], which is oxidized by a BaeyerVilliger monooxygenase to an ester [23-25]. The ester is subsequently hydrolyzed by an esterase to an alcohol and a fatty acid $[19,26]$. In some cases, both ends of the alkane substrate are oxidized, which has been exploited for the production of dicarboxylic acids by yeasts as well as bacteria [27, 28] (Fig. 1).

\section{DIVERSITY OF ALKANE HYDROXYLASE SYSTEMS}

Several unrelated enzyme classes that carry out the oxidation of alkanes have now been characterized (Table 2). A membrane-bound alkane hydroxylase was first discovered in a hexane-degrading fluorescent pseudomonad tentatively named Pseudomonas oleovorans [39, 40], but later identified as a P. putida [41]. Biochemical studies showed that the P. putida alkane hydroxylase system consists of an integral membrane monooxygenase [42-44], 1 or 2 rubredoxins [45-47], and a rubredoxin reductase [48, 49] (Fig. 2). Rubredoxin reductase transfers electrons from NADH (nicotinamide adenine dinucleotide) via its cofactor FAD (flavin adenine dinucleotide) to rubredoxin, which transfers 
TABLE 1

Microorganisms that aerobically degrade aliphatic hydrocarbons

\begin{tabular}{|c|c|c|c|}
\hline Bacteria & Yeasts & Fungi & Algae \\
\hline $\begin{array}{l}\text { Achromobacter } \\
\text { Acinetobacter }(+) \\
\text { Alcanivorax (+) } \\
\text { Alcaligenes } \\
\text { Bacillus } \\
\text { Brevibacterium } \\
\text { Burkholderia (+) } \\
\text { Corynebacterium } \\
\text { Flavobacterium } \\
\text { Mycobacterium (+) } \\
\text { Nocardia } \\
\text { Pseudomonas (+) } \\
\text { Rhodococcus }(+) \\
\text { Sphingomonas } \\
\text { Streptomyces }\end{array}$ & $\begin{array}{l}\text { Candida }(+) \\
\text { Cryptococcus } \\
\text { Debaryomyces (+) } \\
\text { Hansenula } \\
\text { Pichia } \\
\text { Rhodotorula } \\
\text { Saccharomyces } \\
\text { Sporobolomyces } \\
\text { Torulopsis } \\
\text { Trichosporon } \\
\text { Yarrowia (+) }\end{array}$ & $\begin{array}{l}\text { Aspergillus } \\
\text { Cladosporium } \\
\text { Corollasporium } \\
\text { Cunninghamella } \\
\text { Dendryphiella } \\
\text { Fusarium } \\
\text { Gliocladium } \\
\text { Lulworthia } \\
\text { Penicillium } \\
\text { Varicospora } \\
\text { Verticillium }\end{array}$ & Prototheca \\
\hline
\end{tabular}

Information mainly from [7, 18]. A (+) indicates that information on the genetics of alkane degradation is available for strains belonging to the genus. the electrons to the alkane hydroxylase. Recently, enzyme systems related to the $P$. putida GPo1 alkane hydroxylase were cloned from bacterial strains belonging to several different genera [34, 50, 52-54]. While the P. putida GPo1 system acts on alkanes ranging from pentane to dodecane $\left(\mathrm{C}_{5}-\mathrm{C}_{12}\right)[42,55]$, most related membrane-bound alkane hydroxylases solely hydroxylate alkanes containing more than 10 carbon atoms [34] (see below).

Several cytochrome P450 isozymes involved in alkane assimilation were recently cloned from the yeasts Candida maltosa, Yarrowia lipolytica and Debaryomyces hansenii $[29,56,57]$. They belong to the CYP52 gene family of the microsomal class II P450s, and receive electrons from NADPH (nicotinamide adenine dinucleotide phosphate) via FAD- and FMN-containing reductases. The CYP52 enzymes were found to have slightly different substrate specificities: some act primarily on $\mathrm{C}_{12}$ or $\mathrm{C}_{16}$ alkanes, while other enzymes also oxidize fatty acids at the $\omega$-position. The CYP52 gene family may play a significant role in the degradation of alkanes in oil-contaminated environments as yeast and fungi have been shown to overgrow bacteria in sandy soil contaminated with $\mathrm{C}_{10}-\mathrm{C}_{15} n$-alkanes [58].

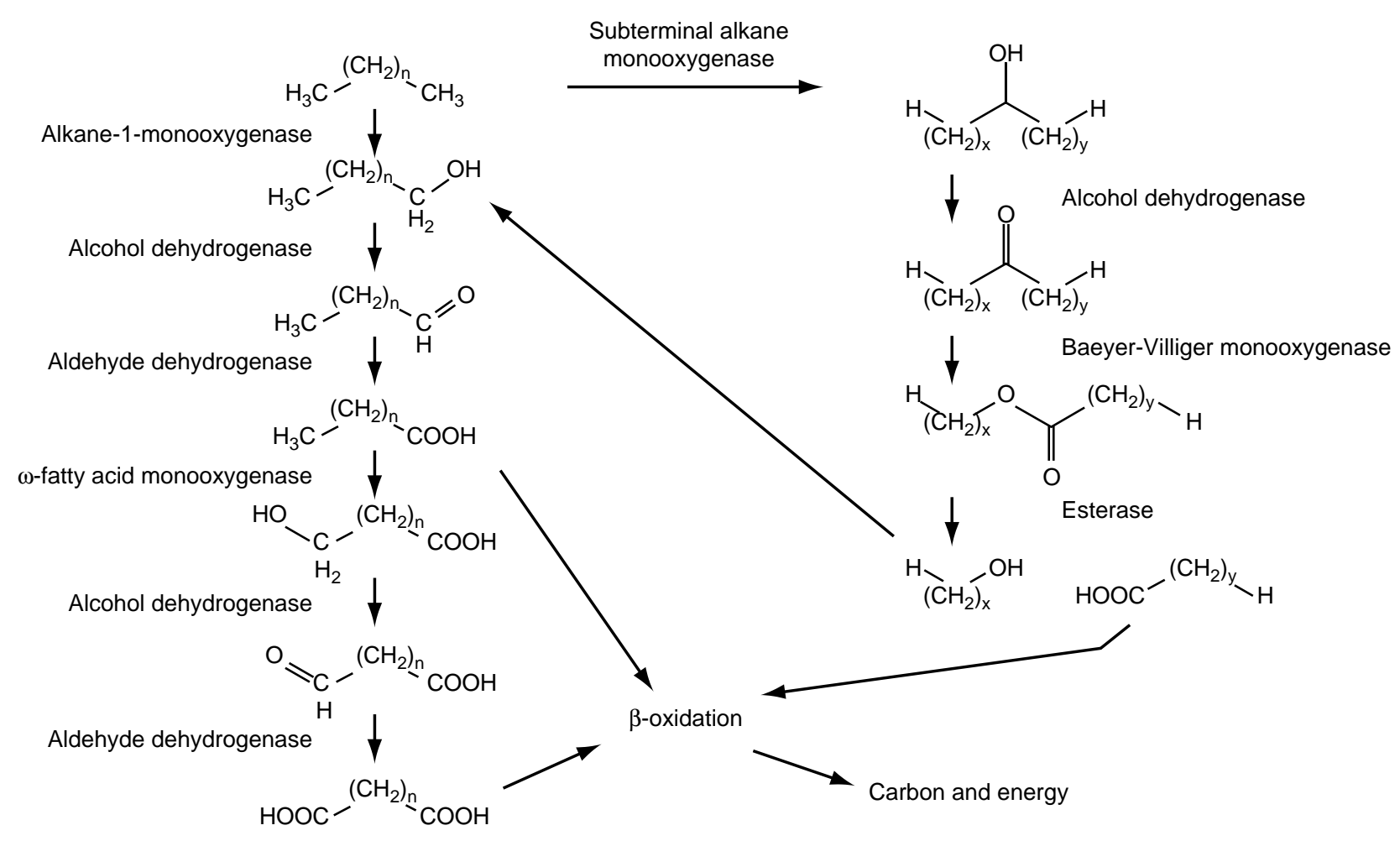

Figure 1

Pathways for the degradation of alkanes by terminal, sub- and biterminal oxidation. Terminal oxidation leads to the formation of fatty acids, which enter the $\beta$-oxidation pathway. Alternatively, $\omega$-hydroxylation by a fatty acid monooxygenase or alkane hydroxylase may take place, leading to dicarboxylic acids. Subterminal oxidation gives rise to secondary alcohols, which are oxidized to ketones. A Baeyer-Villiger monooxygenase converts ketones to esters, which are subsequently cleaved by an esterase. 
TABLE 2

Enzyme classes involved in the oxidation of alkanes

\begin{tabular}{|c|c|c|c|c|}
\hline Enzyme class & Composition and cofactors & Substrate range & Presence shown in: & References \\
\hline $\begin{array}{l}\text { Eukaryotic P450 } \\
(\text { CYP52, class II)) }\end{array}$ & $\begin{array}{l}\text { Microsomal oxygenase: P450 heme } \\
\text { reductase: FAD, FMN, NADPH }\end{array}$ & $\mathrm{C}_{10}-\mathrm{C}_{16} n$-alkanes & $\begin{array}{l}\text { Candida maltosa, Candida tropicalis, } \\
\text { Yarrowia lipolytica }\end{array}$ & {$[29]$} \\
\hline $\begin{array}{l}\text { Bacterial P450 } \\
\text { oxygenase systems } \\
(\mathrm{CYP} 153, \text { class I) }\end{array}$ & $\begin{array}{l}\text { P450 oxygenase: } \mathrm{P} 450 \text { heme } \\
\text { ferredoxin: iron-sulfur } \\
\text { ferredoxin reductase: FAD, NADH }\end{array}$ & $\mathrm{C}_{4}-\mathrm{C}_{16} n$-alkanes & $\begin{array}{l}\text { R. rhodochrous } 7 \mathrm{E} 1 \mathrm{C} \\
\text { Acinetobacter } \mathrm{sp} . \mathrm{EB} 104\end{array}$ & {$[11,30,31]$} \\
\hline $\begin{array}{l}\text { Butane } \\
\text { monooxygenase } \\
(\text { similar to pMMO) }\end{array}$ & $\begin{array}{l}\text { Two polypeptides: copper, iron } \\
\text { quinone oxidoreductase: FAD, NADH }\end{array}$ & $\begin{array}{l}\text { Probably } \mathrm{C}_{4}-\mathrm{C}_{10} \\
n \text {-alkanes }\end{array}$ & $\begin{array}{l}\text { Short-chain alkane oxidizers, } \\
\text { Nocardioides sp. CF8 }\end{array}$ & {$[11,12,32]$} \\
\hline $\begin{array}{l}\text { Butane } \\
\text { monooxygenase } \\
\text { (similar to sMMO) }\end{array}$ & $\begin{array}{l}\alpha 2 \beta 2 \gamma 2 \text { hydroxylase: bi-nuclear iron } \\
\text { reductase: }[2 \mathrm{Fe}-2 \mathrm{~S}], \mathrm{FAD}, \mathrm{NADH} \\
\text { regulatory subunit }\end{array}$ & $\mathrm{C}_{2}-\mathrm{C}_{8} n$-alkanes & Pseudomonas butanovora & {$[11,12,33]$} \\
\hline $\begin{array}{l}\text { AlkB-related } \\
\text { alkane } \\
\text { hydroxylases }\end{array}$ & $\begin{array}{l}\text { Membrane hydroxylase: bi-nuclear iron } \\
\text { rubredoxin: iron } \\
\text { rubredoxin reductase: FAD, NADH }\end{array}$ & $\mathrm{C}_{5}-\mathrm{C}_{16} n$-alkanes & $\begin{array}{l}\text { Acinetobacter, Alcanivorax, } \\
\text { Burkholderia, Mycobacterium, } \\
\text { Pseudomonas, Rhodococcus, etc. }\end{array}$ & [34] \\
\hline Dioxygenase & Homodimer: copper, FAD & $\mathrm{C}_{10}-\mathrm{C}_{30} n$-alkanes & Acinetobacter sp. M-1 & {$[35]$} \\
\hline Unknown & $54 \mathrm{kDa}$ peptide essential for butane oxidation & $\mathrm{C}_{4}-\mathrm{C}_{10} n$-alkanes & Pseudomonas indica IMT37 & {$[36,37]$} \\
\hline $\begin{array}{l}\text { Intermolecular } \\
\text { dioxygenase }\end{array}$ & $\begin{array}{l}\text { Unknown (ratio of hydrocarbon to oxygen } \\
\text { consumption is } 2: 1 \text { ) }\end{array}$ & Propane, isobutane & Rhodococcus rhodochrous & [38] \\
\hline
\end{tabular}

Reports on bacterial cytochrome P450 systems involved in alkane degradation are quite scarce. Cardini and Jurtshuk described a Corynebacterium sp. 7E1C (in recent literature known as Rhodococcus rhodochrous) that contains an octane hydroxylating cytochrome P450 enzyme [59]. Another cytochrome P450 enzyme involved in alkane hydroxylation was isolated [60] and recently cloned from Acinetobacter calcoaceticus EB104 [30]. As this P450 showed less than $40 \%$ sequence identity to other sequences in the P450 superfamily it was assigned to a new bacterial class I P450s family named CYP153. Electron transfer to the bacterial class I enzymes is mediated by ferredoxin reductase, an FAD-containing protein which accepts electrons from $\mathrm{NAD}(\mathrm{P}) \mathrm{H}$, and ferredoxin, an iron-sulfur protein which transfers the electrons to the P450 monooxygenase [61].

Butane-utilizing strains were shown to contain several unrelated alkane hydroxylases, based on responses to ethylene (which inactivates cytochrome $\mathrm{P} 450$ enzymes by alkylating the heme group), acetylene (a mechanism-based inactivator of soluble methane monooxygenases (sMMO), membrane-bound methane monooxygenases (pMMO) and ammonia monooxygenase (AMO)) and allyl thiourea (which chelates copper, and reversibly inhibits pMMO and AMO) [11]. One of these strains, Nocardioides sp. CF8, was shown to contain a membrane-bound alkane hydroxylase related to the $P$. putida GPo1 AlkB, and a copper-dependent light sensitive enzyme similar to pMMO [32]. A butane monooxygenase recently cloned from Pseudomonas butanovora is quite similar to sMMO [12,33]; its protein A $\alpha$ and $\beta$ subunits, and protein B show more than 60,50 , and $40 \%$ amino acid sequence identity, respectively, to the corresponding subunits of sMMOs.

A gene which allows isolates of a novel Pseudomonas sp. named $P$. indica IMT37 [36] to grow on butane had no detectable homology or similarity with other alkane hydroxylase systems [37]. Here, further biochemical work is necessary to elucidate the role of the encoded peptide in butane oxidation. The same holds for a new type of intermolecular dioxygenase, which appears to oxidize two molecules of propane with one molecule of molecular oxygen [38]. A copper-dependent alkane dioxygenase was reported for Acinetobacter sp. M-1 [35], a strain that was later shown to contain two membrane-bound alkane hydroxylases related to $P$. putida GPo1 AlkB as well [54].

\section{DIVERSITY OF MEMBRANE-BO UND ALKANE HYDROXYLASE SYSTEMS}

Biochemical studies and molecular genetic analysis of the $P$. putida GPo1 alkane hydroxylase system have led to a detailed understanding of $\mathrm{C}_{5}-\mathrm{C}_{12} n$-alkane metabolism by this strain [40,41], while other alkane-degraders (except for the methanotrophs) were studied in much less detail. For example, even though hydrocarbon utilization is very common amongst strains belonging to the CorynebacteriumMycobacterium-Nocardia (CMN) complex, until recently only a few CMN strains, such as the $R$. rhodochrous strains 


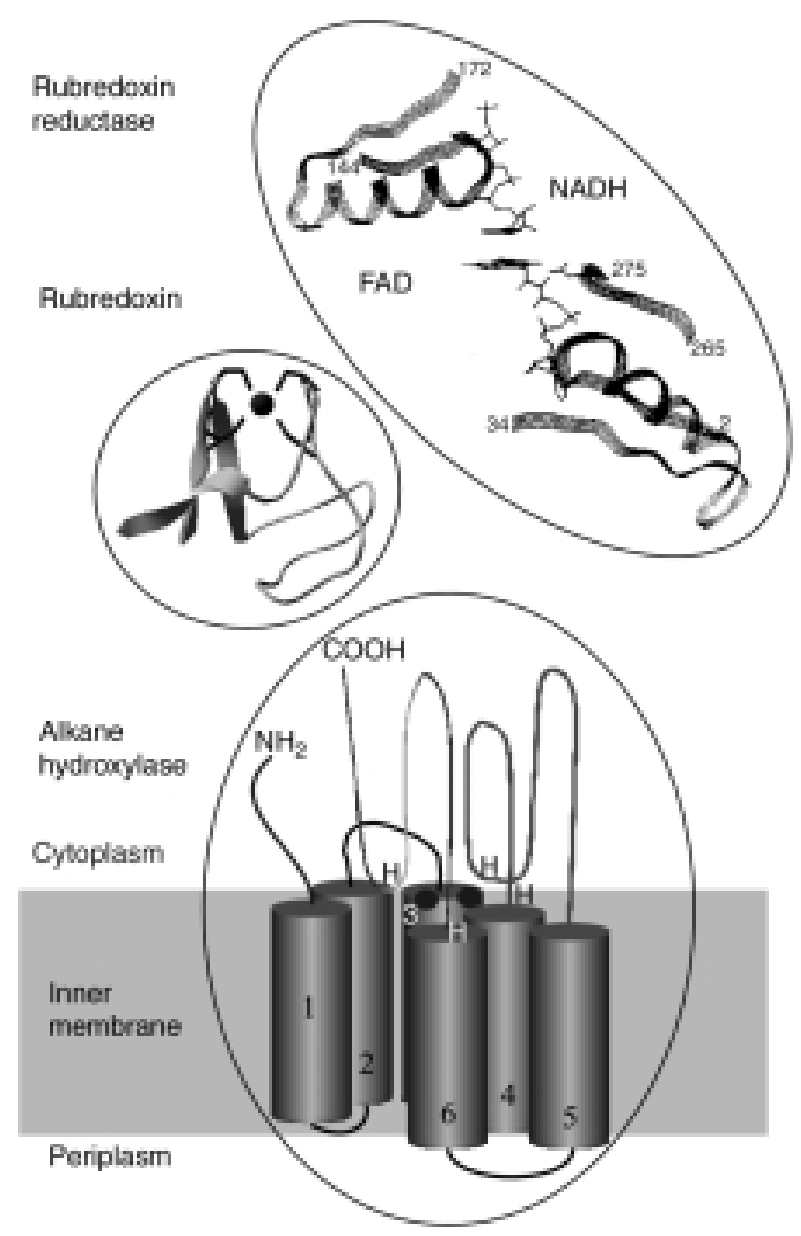

Figure 2

Structure of membrane-bound alkane hydroxylase systems. The membrane-bound alkane hydroxylases possess 6 transmembrane helices [44], and 4 conserved histidine-rich motifs $(\mathrm{H})[50,51]$. The 2 iron atoms in the active site are marked $(\bullet)$. Rubredoxin contains an iron atom marked $(\bullet)$ that is liganded by 4 cysteines. Several strains contain more than 1 rubredoxin, or larger proteins consisting of $\mathrm{N}$-terminal and C-terminal rubredoxin domains connected by a linker [47]. Rubredoxin reductase is an FAD-containing NADHdependent reductase [49].

B29 and 7E1C, were studied in some detail [59, 62]. Several fluorescent pseudomonads that were studied in the sixties and seventies [63-66] were later shown to contain alkane hydroxylase systems that were virtually identical to the $P$. putida GPo1 enzyme [67].

In 1998, a membrane-bound alkane hydroxylase that was quite distantly related to the $P$. putida GPo1 AlkB was cloned from Acinetobacter sp. ADP1, and shown to act on $\mathrm{C}_{12}$ and longer $n$-alkanes [52]. The genome sequence of Mycobacterium tuberculosis $\mathrm{H} 37 \mathrm{Rv}$ [68] was also found to encode an AlkB-homolog, which was later shown to be functional by heterologous expression [34]. Comparison of the three alkane hydroxylase sequences showed that four histidine-containing motifs were well conserved, three of which were also present in the distantly related membranebound desaturases [51]. Based on two of the motifs, highly degenerate primers were developed that amplified internal gene fragments of alkB homologs from gram-negative as well as gram-positive strains [32, 50, 53, 69] (Table 3). In the initial PCR study, most strains that were able to grow on alkanes yielded alkB gene fragments [50], and the same was found for a set of Rhodococcus strains isolated from soil in Bremen, Germany [86, 87]. However, in a collection of 17 hexane-degrading strains isolated from a trickling bed bioreactor that removed hexane from an airstream [88], only 5 strains possessed an alkB-homolog [86]. This suggests that many strains able to degrade shorter alkanes possess enzyme systems that are unrelated to the membrane-bound alkane hydroxylase of $P$. putida GPo1. On the other hand, many strains (especially Rhodococcus and $P$. aeruginosa strains) possess multiple - quite divergent—alkane hydroxylases [67, 86, 89] (Fig. 3, Table 3).

The alkB homologs amplified from the different strains showed high sequence divergence: the branches of a distance tree based on the amino-acid translations of the DNA sequences obtained by the PCR approach, molecular cloning, and genome sequencing had sometimes only $40 \%$ sequence identity (Fig. 3). To demonstrate that the alkB gene homologs indeed encode functional enzymes, special expression vectors [91] and host strains for functional heterologous expression of alkane hydroxylases [34] were constructed. The host strains (Pseudomonas fluorescens KOB $2 \Delta 1$, an alkB knockout derivative of $P$. fluorescens $\mathrm{CHA} 0$, and $P$. putida GPo12(pGEc47 $\Delta \mathrm{B}$ ), a derivative of $P$. putida GPo1 lacking the alkB gene) supply the electron transfer components rubredoxin and rubredoxin reductase, the enzymes that carry out further metabolic steps leading to fatty acids, and, in the case of $P$. fluorescens $\mathrm{KOB} 2 \Delta 1$, also an uptake system for alkanes longer than $\mathrm{C}_{12}$. The host-strains made functional expression of alkane hydroxylases from strains as diverse as Mycobacterium tuberculosis, Prauserella rugosa, Rhodococcus erythropolis, Burkholderia cepacia, Pseudomonas aeruginosa, and Alcanivorax borkumensis possible [34, 53, 89] (marked by "+" in Fig. 3). However, they only allow functional analysis of enzymes that oxidize $n$-alkanes ranging from $\mathrm{C}_{5}-\mathrm{C}_{16}$; alkane hydroxylases which oxidize longer alkanes could not be investigated yet. Additional membranebound alkane hydroxylases were cloned from Acinetobacter sp. strain M-1 and A. calcoaceticus EB104, and shown to be functional by expression in an alkM knockout strain of Acinetobacter sp. ADP1 [50, 54]. Several genome sequences (e. g. Burkholderia mallei, P. aeruginosa, Legionella pneumophilia, M. tuberculosis, Mycobacterium bovis) that have recently become available also contain alkB homologs (marked by "*" in Fig. 3). Most of these bacteria are 
TABLE 3.

Bacterial strains that contain homologs of the P. putida GPo1 alkB gene

\begin{tabular}{|c|c|c|c|c|}
\hline Strain & $\begin{array}{l}\text { Gowth on } \\
n \text {-alkanes }\end{array}$ & $\begin{array}{c}\text { Number of alkB } \\
\text { homologs }\end{array}$ & $\begin{array}{c}\text { Homologs } \\
\text { functional? }\end{array}$ & References \\
\hline Acinetobacter $\mathrm{sp}$. ADP1 & $\mathrm{C}_{12}-\mathrm{C}_{16}$ & 1 & yes & {$[52,70]$} \\
\hline A. calcoaceticus $69-\mathrm{V}$ & $\mathrm{C}_{11}-\mathrm{C}_{18}$ & 1 & n. t. & {$[50,71]$} \\
\hline A. calcoaceticus $\mathrm{EB} 104$ & $\mathrm{C}_{6}-\mathrm{C}_{18}$ & 1 & yes & {$[50,71]$} \\
\hline A. calcoaceticus $\mathrm{NCIB} 8250$ & $\mathrm{C}_{8}-\mathrm{C}_{16}$ & 1 & n. t. & {$[50,72]$} \\
\hline Acinetobacter sp. 2796A & $\mathrm{C}_{10}-\mathrm{C}_{16}$ & 1 & n. t. & {$[50]$} \\
\hline Acinetobacter sp. M-1 & $\mathrm{C}_{13}-\mathrm{C}_{44}$ & 2 & yes & [54] \\
\hline Alcanivorax borkumensis AP1 & $\mathrm{C}_{10}-\mathrm{C}_{16}$ & 2 & yes & {$[34,73]$} \\
\hline A. borkumensis SK2 & $\mathrm{C}_{10}-\mathrm{C}_{16}$ & 2 & n. t. & {$[73]^{*}$} \\
\hline Burkholderia cepacia ATCC 25416 & $\mathrm{C}_{10}-\mathrm{C}_{16}$ & 1 & n. t. & {$[50,74]$} \\
\hline B. серасіa RR10 & $\mathrm{C}_{10}-\mathrm{C}_{16}$ & 1 & yes & [53] \\
\hline B. mallei & $\mathrm{C}_{10}-\mathrm{C}_{16}$ & 1 & n. t. & {$[74]^{* *}$} \\
\hline B. pseudomallei & $\mathrm{C}_{10}-\mathrm{C}_{16}$ & 1 & n. t. & {$[74]^{* *}$} \\
\hline Oleiphilus messinensis ME102 & obligate & 1 & n. t. & [75] \\
\hline Pseudomonas aureofaciens RWTH 529 & $\mathrm{C}_{10}$ & 1 & n. t. & [76] \\
\hline Pseudomonas sp. 7/156 & n. d. & 1 & n. t. & [77] \\
\hline Pseudomonas putida GPo1 & $\mathrm{C}_{5}-\mathrm{C}_{12}$ & 1 & yes & {$[43,78]$} \\
\hline P. putida $\mathrm{P} 1$ & $\mathrm{C}_{8}$ & 1 & yes & {$[41,50]$} \\
\hline Pseudomonas fluorescens $\mathrm{CHA} 0$ & $\mathrm{C}_{12}-\mathrm{C}_{28}$ & 1 & yes & {$[34,79]$} \\
\hline Pseudomonas aeruginosa $\mathrm{PAO} 1$ & $\mathrm{C}_{12}-\mathrm{C}_{16}$ & 2 & yes & {$[34,80]$} \\
\hline P. aeruginosa PG201 & $\mathrm{C}_{10}-\mathrm{C}_{16}$ & 2 & n. t. & {$[81]$} \\
\hline P. aeruginosa KSLA473 & $\mathrm{C}_{5}-\mathrm{C}_{16}$ & 3 & yes & {$[67,82]$} \\
\hline P. aeruginosa NCIMB 8704 & $\mathrm{C}_{8}-\mathrm{C}_{16}$ & 3 & yes & {$[34,67]$} \\
\hline P. aeruginosa NCIMB 9571 & $\mathrm{C} 8-\mathrm{C}_{16}$ & 3 & yes & {$[34,67]$} \\
\hline P. aeruginosa ATCC 17423 & $\mathrm{C} 8-\mathrm{C}_{16}$ & 3 & yes & {$[34,67]$} \\
\hline Mycobacterium avium & paraffins & 1 & n. t. & {$[83]^{* *}$} \\
\hline M. avium subsp. paratuberculosis & paraffins & 1 & n. $t$ & {$[83]^{* *}$} \\
\hline M. bovis $\mathrm{BCG}$ & $\mathrm{C}_{12}-\mathrm{C}_{16}$ & 1 & n. t. & [84] \\
\hline M. smegmatis & $\mathrm{C}_{9}-\mathrm{C}_{16}$ & 1 & n. t. & {$[84]^{* *}$} \\
\hline M. tuberculosis $\mathrm{H} 37 \mathrm{Rv}$ & $\mathrm{C}_{11}-\mathrm{C}_{16}$ & 1 & yes & {$[34,68,84]$} \\
\hline Nocardioides sp. CF8 & $\mathrm{C}_{2}-\mathrm{C}_{16}$ & 1 & n. t. & [32] \\
\hline Prauserella rugosa NRRL B-2295 & $\mathrm{C}_{8}-\mathrm{C}_{14}$ & 1 & yes & {$[34,85]$} \\
\hline Rhodococcus sp. 1BN & $\mathrm{C}_{6}-\mathrm{C}_{28}$ & 1 & n. t. & [69] \\
\hline Rhodococcus erythropolis $\mathrm{Q} 15$ & $\mathrm{C}_{8}-\mathrm{C}_{32}$ & 4 & 1 yes, 3 no & [21] \\
\hline R. erythropolis $35-\mathrm{O}$ & $\mathrm{C}_{6}-\mathrm{C}_{16}$ & 5 & n. t. & {$[86]$} \\
\hline R. erythropolis $42-\mathrm{O}$ & $\mathrm{C}_{6}-\mathrm{C}_{32}$ & 5 & n. t. & [86] \\
\hline R. erythropolis $62-\mathrm{O}$ & $\mathrm{C}_{6}-\mathrm{C}_{16}$ & 5 & n. t. & [86] \\
\hline R. erythropolis 23-D & $\mathrm{C}_{6}-\mathrm{C}_{36}$ & 5 & n. t. & [86] \\
\hline R. erythropolis $50-\mathrm{V}$ & $\mathrm{C}_{6}-\mathrm{C}_{32}$ & 4 & n. t. & [86] \\
\hline R. erythropolis NRRL B- 16531 & $\mathrm{C}_{6}-\mathrm{C}_{36}$ & 4 & 1 yes, 3 no & [85] \\
\hline Rhodococcus fascians $115-\mathrm{H}$ & $\mathrm{C}_{6}-\mathrm{C}_{32}$ & 3 & n. t. & [86] \\
\hline R. fascians $154-\mathrm{S}$ & $\mathrm{C}_{6}-\mathrm{C}_{24}$ & 4 & n. t. & [86] \\
\hline
\end{tabular}

* J.B. van Beilen, unpublished data.

** data from unfinished genome sequence. 


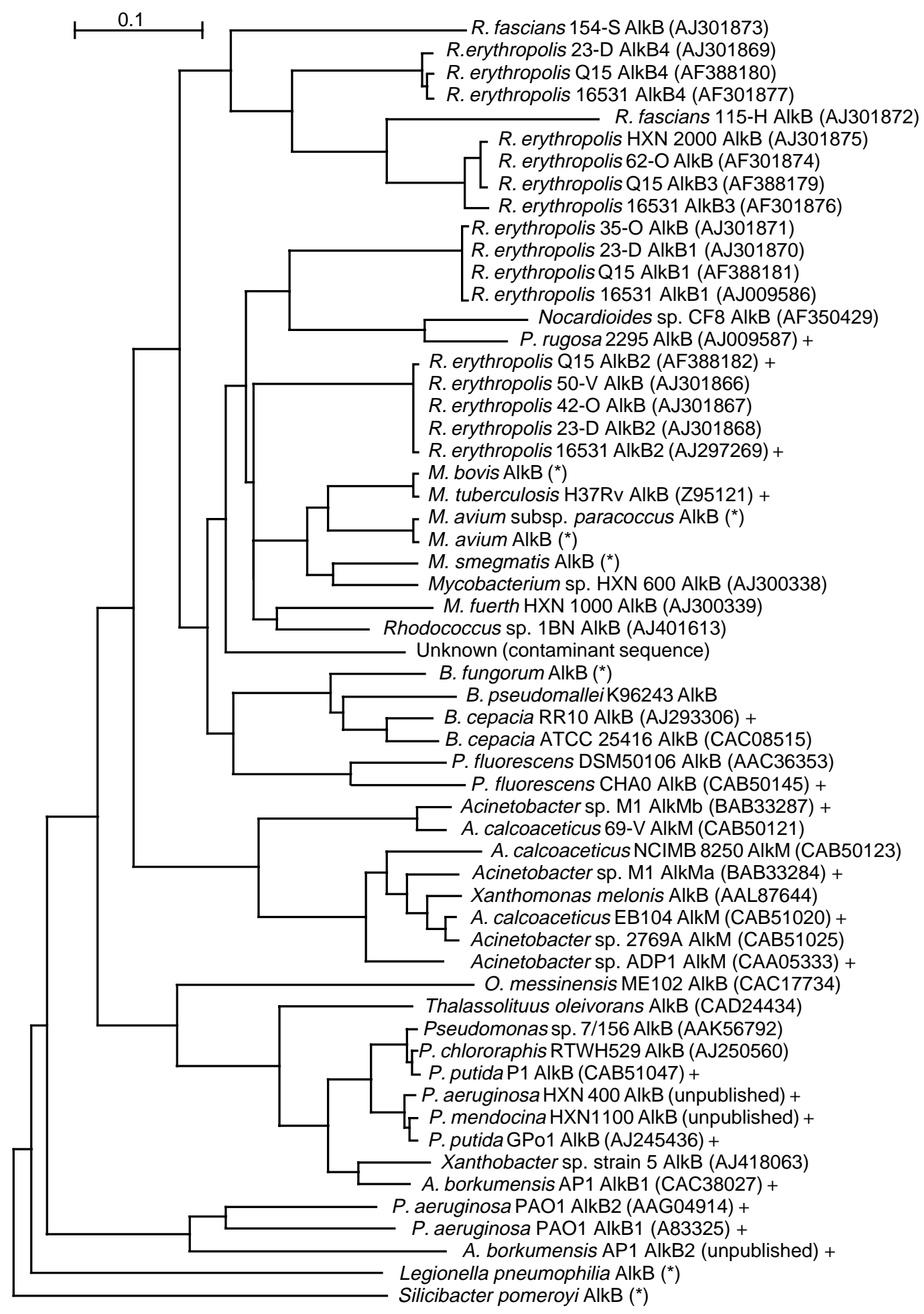

Figure 3

Unrooted phylogenetic tree based on an alignment of partial amino acid sequences of (putative) membrane-bound alkane hydroxylases. The distance tree was generated by ClustalX [90] from a manual alignment of the (putative) alkane hydroxylases. Only the segment corresponding to the 550 basepair fragments obtained in PCR experiments with highly degenerate primers based on histidine box 1 and histidine box 4 were used for the alignment. Alkane hydroxylases that were shown to be functional by heterologous expression or gene knockouts are indicated by $(+)$, while sequences from unfinished genome sequences are indicated by $(*)$. Scale bar, 0.1 substitution per amino-acid site. 
facultative pathogens that may utilize alkanes as a carbonsource in environments such as soil or water.

A careful inspection of the distance tree shows that there is no clear linkage between the diversity of the alkB genes and phylogenetic lines (Fig. 3). For example, AlkB homologs from fluorescent pseudomonads are almost as divergent as the entire collection, while the four AlkB-homologs in $R$. erythropolis NRRL B-16531 and Q15 are as divergent as the whole set of sequences from gram-positive strains [89]. Some strains contain multiple AlkB sequences that are on completely different branches-A. borkumensis, and several $P$. aeruginosa strains that are able to grow on $n$-octane as well as the longer $n$-alkanes (Smits et al., submitted; van Beilen, unpublished data). On the other hand, the Burkholderia and P. fluorescens sequences are so closely related to some sequences from gram-positive strains that cross-reactions in Southern and dot-blots are possible (>70\%
DNA sequence identity). In part, the failing link between phylogenetic lineage and AlkB-diversity is clearly due to horizontal gene transfer. For example, the P. putida GPo1 alk-genes are located on a large broad host-range plasmid named OCT [92], while the closely related $P$. putida P1 alkgenes are located on a class I transposon [41].

Our present knowledge on the structure-function relationship of the class of integral membrane alkane hydroxylases is limited to the folding topology [44] and the likely involvement of conserved histidines in binding of the 2 active-site iron atoms [51]. The AlkB sequences show significant sequence divergence, but the membrane folding of these alkane hydroxylases appears to follow the same pattern: the 6 hydrophobic stretches that are likely to span the cytoplasmic membrane [51] (Fig. 2) are highly conserved in all sequences, while the same is true for the conserved histidines. It is not yet possible to identify residues involved

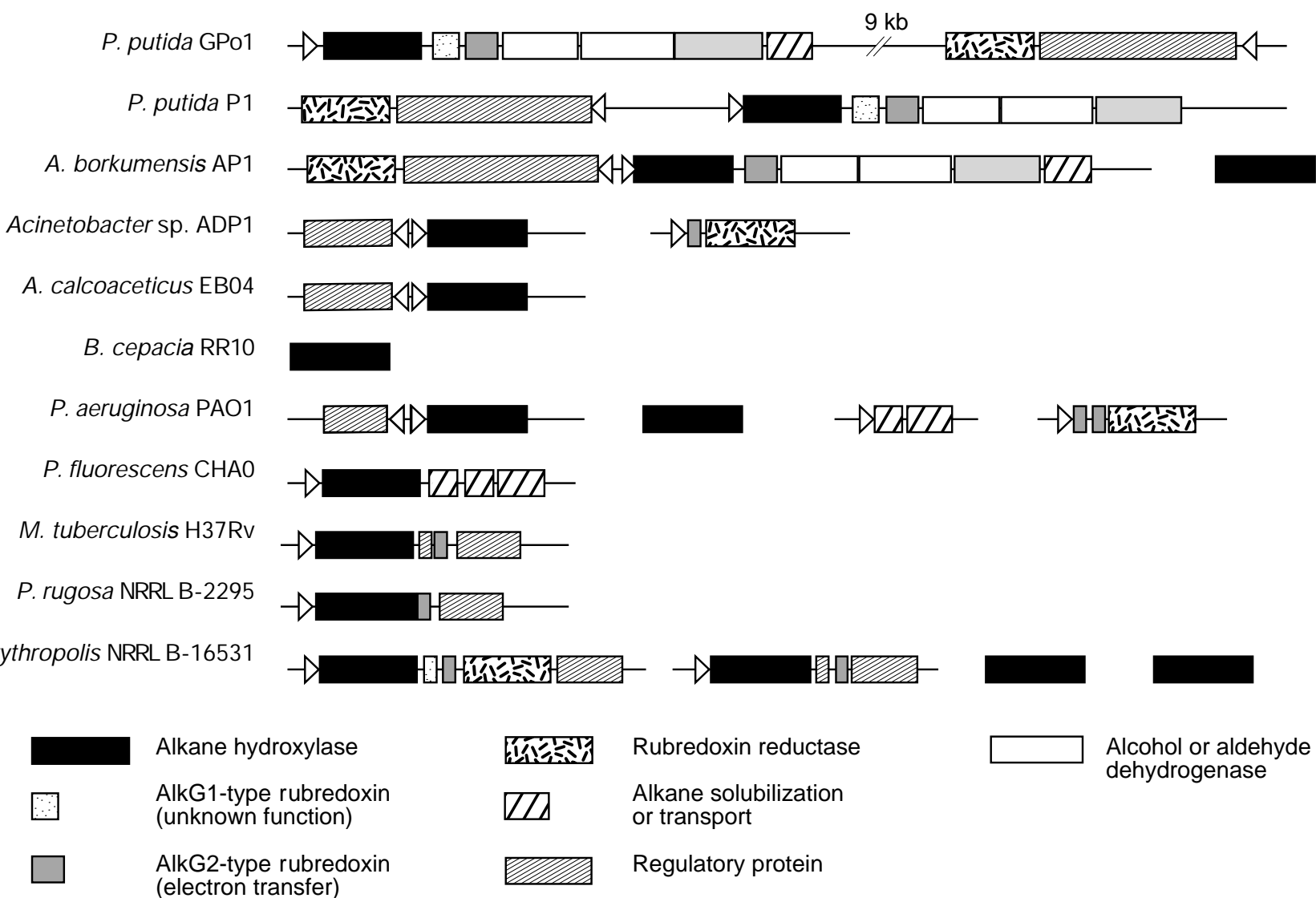

Figure 4

Organization of alk genes in different microorganisms. The function of the encoded proteins is indicated below. If the ORFs are linked by a line, the sequence is contiguous. If the ORFs are not linked by a line, the genes are located elsewhere on the chromosome. The triangle indicates the direction of transcription. 
in other aspects of alkane hydroxylase function. Residues that are involved in binding of rubredoxin are likely to be conserved between all alkane hydroxylases, as rubredoxins can be exchanged between alkane hydroxylase systems from all strains tested [47]. However, these residues cannot be distinguished from other conserved residues. Similarly, the three medium chain-length alkanes hydroxylases from P. putida GPo1, P. putida P1, and A. borkumensis AP1 are too closely related to each other to distinguish residues conserved by chance from residues conserved because of functional constraints.

The organization of genes involved in alkane oxidation varies strongly among the different alkane degrading bacteria (Fig. 4). In most strains, genes involved in alkane degradation seem to be distributed over the genome. Except in the case of $R$. erythropolis [89], none of the rubredoxin reductase genes is located close to an alkane hydroxylase, perhaps because they are also involved in other pathways, and require a different type of regulation. In contrast, most rubredoxin genes are located immediately downstream of the alkane hydroxylase genes. Those that are located elsewhere are encoded directly upstream of rubredoxin reductase genes. Interestingly, the alk-gene cluster around alkB1 of A. borkumensis (a recently discovered seawater bacterium that only grows on alkanes [73]) is very similar to the alk gene clusters of $P$. putida strains GPo1 and P1, with respect to gene organization as well as sequence. The $P$. putida alk genes have a significantly lower $\mathrm{G}+\mathrm{C}$ content than the rest of the genome, and are encoded on a putative catabolic transposon [41]. These comparisons suggest that the A. borkumensis alk genes may have ended up in this strain by horizontal gene transfer as well. Interestingly, the alkane hydroxylase genes are accompanied by alcohol and aldehyde dehydrogenase genes only in these strains (Fig. 4).

\section{DETECTION OF ALKANE HYDROXYLASE GENES IN THE EN VIRONMENT}

Most of the enzyme systems described above have been discovered recently, and evidence that similar systems are present in other bacteria is still scarce. A gene probe based on the IMT37 sequence essential for butane oxidation detected

TABLE 4

Studies on the occurrence, abundance, and/or diversity of alkB-homologues in different environments or strain collections

\begin{tabular}{|c|c|c|c|}
\hline Environment/source & Methods & Conclusions for alkB homologs & References \\
\hline Alaskan sediments & $\begin{array}{l}\text { Colony hybridization with } a l k B \\
\text { gene probe }\end{array}$ & $\begin{array}{l}39 \% \text { of viable heterotrophs from uncontaminated soil contain alkB } \\
67 \% \text { of viable heterotrophs from contaminated soil contain alkB }\end{array}$ & [97] \\
\hline Contaminated soil & $\begin{array}{l}\text { PCR followed by Southern blot } \\
\text { with alkB gene probe }\end{array}$ & $\begin{array}{l}\text { Detection and quantification of } a l k B \text { (and other genes) in soil: 1-10 } \\
\text { gene copies per gram of soil can be detected }\end{array}$ & {$[98$} \\
\hline Variety of cold ecosystems & $\begin{array}{l}\text { PCR, and Southern blots } \\
\text { with alkB gene probe }\end{array}$ & $\begin{array}{l}\text { None of the psychrophilic alkane degraders possess genes } \\
\text { with high homology to } P \text {. putida alkB }\end{array}$ & [99] \\
\hline Fuel oil-contaminated site & Dot-blots & $\begin{array}{l}\text { DNA extracted from soil shows no significant hybridization } \\
\text { with an } a l k B \text {-gene probe }\end{array}$ & [100] \\
\hline Shallow aquifer & $\begin{array}{l}\text { Southern blots } \\
\text { with alkB gene probe }\end{array}$ & $\begin{array}{l}10-20 \% \text { of the total bacterial community hybridizes } \\
\text { with an alkB gene probe }\end{array}$ & [101] \\
\hline $\begin{array}{l}\text { Various sources } \\
\text { ( } 54 \text { bacterial strains })\end{array}$ & $\begin{array}{l}\text { PCR with highly degenerate } \\
\text { primers for alkB homologs }\end{array}$ & $\begin{array}{l}\text { Most alkane-degrading strains contain distantly related alkB homologs } \\
\text { (homology not sufficient for Southern or dot-blots) }\end{array}$ & {$[50]$} \\
\hline $\begin{array}{l}\text { Shallow aquifer } \\
\text { (natural attenuation site) }\end{array}$ & $\begin{array}{l}\text { Dot-blots with DNA extracted } \\
\text { from aquifer samples }\end{array}$ & $\begin{array}{l}\text { alkB genotypes start at } 11 \% \text { of total community, and peak at } \\
52 \% \text { after injection of synthetic jet fuel in the aquifer }\end{array}$ & [102] \\
\hline $\begin{array}{l}\text { Various sources } \\
\text { ( } 54 \text { bacterial strains })\end{array}$ & $\begin{array}{l}\text { Southern, colony and dot-blots, } \\
\text { PCR followed by Southern }\end{array}$ & $\begin{array}{l}\text { alkB genes (close homologs) are widespread only in short-chain } n \text {-alkane } \\
\text { degrading pseudomonads }\end{array}$ & {$[76]$} \\
\hline Rhizosphere $v s$. bulk soil & Multiplex PCR & $\begin{array}{l}\text { At a contaminated site } a l k B \text { was } 10 \text { times more prevalent } \\
\text { in the endophytic community compared to the bulk soil community }\end{array}$ & {$[103]$} \\
\hline $\begin{array}{l}\text { Propane and butane- } \\
\text { utilizing bacteria }\end{array}$ & Dot-blots & $\begin{array}{l}8 \text { of } 15 \text { strains (including pseudomonads and rhodococci) } \\
\text { gave a strong signal, and } 7 \text { a weak signal with the IMT37 gene }\end{array}$ & {$[37]$} \\
\hline Land treatment unit (LTU) & $\begin{array}{l}\text { PCR, terminal restriction } \\
\text { fragment length polymorphism }\end{array}$ & $\begin{array}{l}\text { alkB increased in abundance during the first } 3 \text { weeks of LTU operation, } \\
\text { and comprised }>80 \% \text { of the total PCR products }\end{array}$ & {$[104]$} \\
\hline Arctic and Antarctic soil & $\begin{array}{l}\text { PCR-hybridization } \\
\text { and colony hybridization }\end{array}$ & $\begin{array}{l}\text { Rhodococcal alkB genes occur in contaminated and pristine soils, } \\
P \text {. putida alkB occurs more frequently in contaminated soils }\end{array}$ & [105] \\
\hline
\end{tabular}


similar genes in other butane degraders (pseudomonads, rhodococci and unidentified bacteria). In a dot-blot experiment, 8 out of 15 propane or butane-degrading bacteria gave a strong signal with the gene-probe, while the remaining 7 gave a weak but detectable signal [37].

The prevalence in the environment of the CYP153 P450 alkane hydroxylase family, the first member of which was recently cloned from Acinetobacter sp. EB104 [30], and the yeast CYP52 P450 family, has not been investigated yet. However, hexane or octane inducible cytochrome P450s were detected in several Rhodococcus, Bacillus megaterium and Candida apicola strains [59, 93]. Indications that the butane monooxygenases studied by Arp and coworkers [11, $32,33]$ are also widespread come from studies on the cometabolic degradation of TCE and other chlorinated compounds by bacteria growing on short-chain alkanes [ 9 , 11]. Soluble and particular MMOs are known to oxidize the same compounds [20], and are ubiquitous in many environments (see for example [94-96]). This also implies that some of the gene diversity detected with primers that amplify pMMO and sMMO genes may well be due to shortchain alkane-degrading bacteria instead of methanotrophs.

Because the sequence of the P. putida GPo1 alkB gene was already published in 1989 [43], several research groups have used this gene as a probe in ecological studies, with conflicting results (Table 4). While in some studies alkB homologs were detected in $10-40 \%$ of the bacterial population [97, 101, 102], other groups did not detect alkB homologs at all $[99,100]$. AlkB homologs that are closely related to the $P$. putida GPo1 enzyme appear to be common in gram-negative strains only (probably pseudomonads) [76]. This is supported by the observation that genes almost identical to the $P$. putida GPo1 alkB gene were found in several $P$. putida, $P$. aeruginosa, and $P$. mendocina strains [67, 87], but not in other strains. An exception is the alkB1 gene found in A. borkumensis AP1, which is sufficiently closely related to the $P$. putida alkB genes for cross-reactions in Southern blots. This supports the notion that horizontal gene transfer has played a role in spreading this genotype [34]. Rhodococcal alkB homologs were only cloned recently $[50,86,89]$, but first reports indicate that these genotypes are widespread in Arctic and Antarctic soils, and in other environments $[86,105]$.

\section{APPLCATIONS OF ALKANE HYDROXYLASE SYSTEMS}

A strong incentive for research on alkane hydroxylases was the early observation that the $P$. putida alkane hydroxylase oxidizes alkenes to epoxides [106], while $P$. aeruginosa KSLA 473 (which contains an enzyme system that is identical to the P. putida GPo1 alkane hydroxylase [67]) hydroxylates a wide range of branched and cyclic alkanes, and alkylbenzenes [107]. P. putida GPo1 was found to oxidize many other substrates as well (including ethylsubstituted heterocyclic compounds, allyl phenyl or allyl benzyl ethers, thioethers, branched alkanes, etc.) with excellent regio- and/or stereoselectivity [16, 55, 108-111]. Screening of a collection of alkane-degrading strains for the regio- and stereoselective hydroxylation of $\mathrm{N}$-benzylpyrrolidine showed that $25-30 \%$ of the strains oxidized this substrate to $\mathrm{N}$-benzyl-3-hydroxypyrrolidine with varying enantiomeric excess [110]. The best strain in this study was a hexane-degrading Sphingomonas sp. strain HXN200, isolated from the trickling-bed filter mentioned earlier [88]. In subsequent work, Sphingomonas sp. strain HXN200 was shown to hydroxylate many 4-, 5,- and 6-ring alicyclic compounds with rates of up to $10-20 \mu \mathrm{mol} \mathrm{min}^{-1} \mathrm{~g}^{-1}$ cell dry weight $[17,112,113]$. The stereoselective oxidation of isopropyl moieties by alkane-grown Rhodococcus and Pseudomonas strains has also been studied in some detail $[85,114,115]$.

A new application area of alkane hydroxylases is the cometabolic degradation of TCE, MTBE, and related compounds by bacteria able to grow on short-chain alkanes (typically propane to pentane) [8, 116-120]. The propane and TCE degrading strain $P$. butanovora was shown to contain butane monooxygenase genes that were closely related to sMMO [33].

\section{CONCLUSIONS AND OUTLOOK}

Alkanes are ubiquitous in the environment due to biogenic production and oil pollution, and many aerobic microorganisms are able to use these highly reduced hydrocarbons as a sole carbon- and energy source. The oxygenases that are required for the initial activation of alkanes belong to several different enzyme classes, some of which only oxidize shortchain alkanes, while others oxidize medium and long-chain alkanes. Membrane-bound alkane hydroxylases related to AlkB of P. putida GPo1 have been found in many bacteria able to grow on $\mathrm{C}_{5}-\mathrm{C}_{16}$ alkanes, and have also been detected in environments such as soils and aquifers. Other enzyme systems involved in alkane assimilation have been studied only in a limited number of strains (often just 1 or 2). Future research efforts are likely to yield additional and perhaps completely novel alkane hydroxylase systems. A major challenge will be to explain the parallel evolution of such diverse families of alkane hydroxylases with essentially the same function. For this purpose, the roles of the individual enzyme systems in their hosts and ecological niches need to be assessed in detail. Important elements in the required physiological studies will be the quantification of kinetic parameters such as the $\mathrm{k}_{\mathrm{cat}}$ and $\mathrm{K}_{\mathrm{m}}$ of various enzyme systems for a variety of alkanes and oxygen, according to standardized protocols. Potential applications in 
bioremediation and biocatalysis are a strong incentive to study cometabolic oxidations by alkane hydroxylase systems in much greater detail. Studies of alkane hydroxylase gene diversity, coupled with information on substrate range, induction, enzyme kinetics and host properties, should help to optimize the biodegradative activity of indigenous hydrocarbon degrading strains, benefit biocatalytic applications, and promote fundamental research on the activation of oxygen by enzymes and biomimetic catalysts.

\section{REFEREN CES}

1 Rosenberg, E., and Ron, E.Z. (1996) Bioremediation of Petroleum Contamination, in Bioremediation: Principles and Applications, Crawford, R.L., and Crawford, D.L. (Eds.) Cambridge University Press, Cambridge.

2 National Research Council (2002) Oil in the Sea III: Inputs, Fates, and Effects, National Academy Press, Washington DC.

3 Söhngen, N.L. (1906) Ueber Bakterien, welche Methan als Kohlenstoffnahrung und Energiequelle gebrauchen. Centralbl. Bakt. etc. Abt. II, 15, 513-517.

4 Söhngen, N.L. (1913) Benzin, Petroleum, Paraffinöl und Paraffin als Kohlenstoff- und Energiequelle für Mikroben. Zentr. Bacteriol. Parasitenk., Abt. II, 37, 595-609.

5 Brisbane, P.G., and Ladd, J.N. (1965) The Role of Microorganisms in Petroleum Exploration. Annu. Rev. Microbiol., 19.

6 Boulton, C.A., and Ratledge, C. (1984) The Physiology of Hydrocarbon-Utilizing Microorganisms. Top. Enzyme Ferment. Biotechnol., 9, 11-77.

7 Bühler, M., and Schindler, J. (1984) Aliphatic Hydrocarbons. In: Biotransformations, Kieslich, K. (Ed.), Verlag Chemie Weinheim, Weinheim.

8 Steffan, R.J., McClay, K., Vainberg, S., Condee, C.W., and Zhang, D. (1997) Biodegradation of the Gasoline Oxygenates Methyl Tert-Butyl Ether, Ethyl Tert-Butyl Ether, and TertAmyl Methyl Ether by Propane-Oxidizing Bacteria. Appl. Environ. Microbiol., 63, 4216-4222.

9 Chang, H.S., and Alvarez Cohen, L. (1995) Transformation Capacities of Chlorinated Organics by Mixed Cultures Enriched on Methane, Propane, Toluene, or Phenol. Biotechnol. Bioeng., 45, 440-449.

10 Britton, L.N. (1984) Microbial Degradation of Aliphatic Hydrocarbons. In: Microbial Degradation of Organic Compounds Gibson, D.T. (Ed.) Marcel Dekker, New York.

11 Hamamura, N., Storfa, R.T., Semprini, L., and Arp, D.J. (1999) Diversity in Butane Monooxygenases Among ButaneGrown Bacteria. Appl. Environ. Microbiol., 65, 4586-4593.

12 Murrell, J.C., Gilbert, B., and McDonald, I.R. (2000) Molecular Biology and Regulation of Methane Monooxygenase. Arch. Microbiol., 173, 325-332.

13 Labinger, J.A., and Bercaw, J.E. (2002) Understanding and Exploiting C-H Bond Activation. Nature, 417, 507-514.

14 Heider, J., Spormann, A.M., Beller, H.R., and Widdel, F. (1998) Anaerobic Bacterial Metabolism of Hydrocarbons. FEMS Microbiol. Rev., 22, 5, 459-473.

15 Hayaishi, O., Katagiri, M., and Rothberg, S. (1955) Mechanism of the Pyrocatechase Reaction. J. Am. Chem. Soc., 77, 5450-5451.
16 Witholt, B., de Smet, M.J., Kingma, J., van Beilen, J.B., Kok, M., Lageveen, R.G., and Eggink, G. (1990) Bioconversions of Aliphatic Compounds by Pseudomonas oleovorans in Multiphase Biorectors: Background and Economic Potential. Trends Biotechnol., 8, 46-52.

17 Li, Z., Feiten, H.J., Chang, D., Duetz, W.A., van Beilen, J.B., and Witholt, B. (2001) Preparation of $(R)$ - and $(S)-N$ Protected-3-Hydroxypyrrolidines by Hydroxylation with Sphingomonas sp. HXN-200, a Highly Active, Regio-and Stereoselective, and Easy to Handle Biocatalyst. J. Org. Chem., 66, 8424-8430.

18 Watkinson, R.J., and Morgan, P. (1990) Physiology of Aliphatic Hydrocarbon-Degrading Micro-Organisms. Biodegradation, 1, 79-92.

19 Ashraf, W., Mihdhir, A., and Murrell, J.C. (1994) Bacterial Oxidation of Propane. FEMS Microbiol. Lett., 122, 1-6.

20 Sullivan, J.P., Dickinson, D., and Chase, H.A. (1998) Methanotrophs, Methylosinus trichosporium OB3b, sMMO, and their Application to Bioremediation. Crit. Rev. Microbiol., 24, 335-373.

21 Whyte, L.G., Hawari, J., Zhou, E., Bourbonnière, L., Inniss, W.E., and Greer, C.W. (1998) Biodegradation of VariableChain-Length Alkanes at Low Temperatures by a Psychrotrophic Rhodococcus sp. Appl. Environ. Microbiol., 64, 2578-2584.

22 Forney, F.W., and Markovetz, A.J. (1970) Subterminal Oxidation of Aliphatic Hydrocarbons. J. Bacteriol., 102, 281-282.

23 Forney, F.W., and Markovetz, A.J. (1968) Oxidative Degradation of Methyl Ketones II. Chemical Pathway for Degradation of 2-Tridecanone by Pseudomonas multivorans and Pseudomonas aeruginosa. J. Bacteriol., 96, 1055-1064.

24 Forney, F.W., Markovetz, A.J., and Kallio, R.E. (1967) Bacterial Oxidation of 2-Tridecanone to 1-Undecanol. J. Bacteriol., 93, 649-655.

25 Britton, L.N., and Markovetz, A.J. (1977) A Novel Ketone Monooxygenase from Pseudomonas cepacia. Purification and Properties. J. Biol. Chem., 252, 8561-8566.

26 Shum, A.C., and Markovetz, A.J. (1974) Purification and Properties of Undecyl Acetate Esterase from Pseudomonas cepacia Grown on 2-Tridecanone. J. Bacteriol., 118, 880-889.

27 Scheller, U., Zimmer, T., Becher, D., Schauer, F., and Schunck, W.H. (1998) Oxygenation Cascade in Conversion of $n$-Alkanes to $\alpha, \omega$-Dioic Acids Catalyzed by Cytochrome P450 52A3. J. Biol. Chem., 273, 32528-32534.

28 Broadway, N.M., Dickinson, F.M., and Ratledge, C. (1993) The Enzymology of Dicarboxylic Acid Formation by Corynebacterium sp. Strain 7E1C Grown on $n$-Alkanes. J. Gen. Microbiol., 139, 1337-1344.

29 Iida, T., Sumita, T., Ohta, A., and Takagi, M. (2000) The Cytochrome P450ALK Multigene Family of an $n$-AlkaneAssimilating Yeast, Yarrowia lipolytica: Cloning and Characterization of Genes Coding for New CYP52 Family Members. Yeast, 16, 1077-1087.

30 Maier, T., Foerster, H.H., Asperger, O., and Hahn, U. (2001) Molecular Characterization of the 56-kDa CYP153 from Acinetobacter sp. EB104. Biochem. Biophys. Res. Commun., 286, 652-658.

31 Cardini, G., and Jurtshuk, P. (1968) Cytochrome P-450 Involvement in the Oxidation of $n$-Octane by Cell-Free Extracts of Corynebacterium sp. Strain 7E1C. J. Biol. Chem., 243, 6070-6072.

32 Hamamura, N., Yeager, C. M., and Arp, D. J. (2001) Two Distinct Monooxygenases for Alkane Oxidation in Nocardioides sp. Strain CF8. Appl. Environ. Microbiol., 67, 4992-4998. 
33 Sluis, M.K., Sayavedra Soto, L.A., and Arp, D.J. (2002) Molecular Analysis of the Soluble Butane Monooxygenase from "Pseudomonas butanovora". Microbiology, 148, 36173629.

34 Smits, T.H.M., Balada, S.B., Witholt, B., and van Beilen, J.B. (2002) Functional Analysis of Alkane Hydroxylases from Gram-Negative and Gram-Positive Bacteria. J. Bacteriol., 184, 1733-1742.

35 Maeng, J.H., Sakai, Y., Tani, Y., and Kato, N. (1996) Isolation and Characterization of a Novel Oxygenase that Catalyzes the First Step of $n$-Alkane Oxidation in Acinetobacter sp Strain M-1. J. Bacteriol., 178, 3695-3700.

36 Pandey, K.K., Mayilray, S., and Chakrabarti, T. (2002) Pseudomonas indica sp. Nov., a Novel Butane Utilizing Species. Int. J. Syst. Evol. Microbiol., 52, 1559-1567.

37 Padda, R S., Pandey, K.K., Kaul, S., Nair, V D., Jain, R.K., Basu, S.K., and Chakrabarti, T. (2001) A Novel Gene Encoding a $54 \mathrm{kDa}$ Polypeptide is Essential for Butane Utilization by Pseudomonas sp. IMT37. Microbiology, 147, 2479-2491.

38 Babu, J.P., and Brown, L.R. (1984) New Type of Oxygenase Involved in the Metabolism of Propane and Isobutane. Appl. Environ. Microbiol., 48, 260-264.

39 Baptist, J.N., Gholson, R.K., and Coon, M.J. (1963) Hydrocarbon Oxidation by a Bacterial Enzyme System: I Products of Octane Oxidation. Biochim. Biophys. Acta, 69, 40-47.

40 van Beilen, J.B., Wubbolts, M.G., and Witholt, B. (1994) Genetics of Alkane Oxidation by Pseudomonas oleovorans. Biodegradation, 5, 161-174.

41 van Beilen, J.B., Panke, S., Lucchini, S., Franchini, A.G., Röthlisberger, M., and Witholt, B. (2001) Analysis of Pseudomonas putida Alkane Degradation Gene Clusters and Flanking Insertion Sequences: Evolution and Regulation of the Alk-Genes. Microbiology, 147, 1621-1630.

42 McKenna, E.J., and Coon, M.J. (1970) Enzymatic $\omega$-Oxidation. IV. Purification and Properties of the $\omega$-Hydroxylase of Pseudomonas Oleovorans. J. Biol. Chem., 245, 3882-3889.

43 Kok, M., Oldenhuis, R., van der Linden, M.P.G., Raatjes, P., Kingma, J., van Lelyveld, P.H., and Witholt, B. (1989) The Pseudomonas oleovorans Alkane Hydroxylase Gene. Sequence and Expression. J. Biol. Chem., 264, 5435-5441.

44 van Beilen, J.B., Penninga, D., and Witholt, B. (1992) Topology of the Membrane-Bound Alkane Hydroxylase of Pseudomonas oleovorans. J. Biol. Chem., 267, 9194-9201.

45 Peterson, J.A., and Coon, M J. (1968) Enzymatic $\omega$ oxidation. III. Purification and Properties of Rubredoxin, a Component of the $\omega$-Hydroxylation System of Pseudomonas oleovorans. J. Biol. Chem., 243, 329-334.

46 Kok, M., Oldenhuis, R., van der Linden, M.P.G., Meulenberg, C.H.C., Kingma, J., and Witholt, B. (1989) The Pseudomonas oleovorans AlkBAC Operon Encodes Two Structurally Related Rubredoxins and an Aldehyde Dehydrogenase. J. Biol. Chem., 264, 5442-5451.

47 van Beilen, J.B., Neuenschwander, M., Smits, T.H.M., Roth, C., Balada, S.B., and Witholt, B. (2002) Rubredoxins Involved in Alkane Oxidation. J. Bacteriol., 184, 1722-1732.

48 Ueda, T., and Coon, M.J. (1972) Enzymatic $\omega$-Oxidation. VII. Reduced Diphosphopyridine Nucleotide-Rubredoxin Reductase: Properties and Function as an Electron Carrier in w-Hydroxylation. J. Biol. Chem., 247, 5010-5016.

49 Eggink, G., Engel, H., Vriend, G., Terpstra, P., and Witholt, B. (1990) Rubredoxin Reductase of Pseudomonas oleovorans. Structural Relationship to Other Flavoprotein
Oxidoreductases Based on One NAD and Two FAD Fingerprints. J. Mol. Biol., 212, 135-142.

50 Smits, T.H.M., Röthlisberger, M., Witholt, B., and van Beilen, J.B. (1999) Molecular Screening for Alkane Hydroxylase Genes in Gram-Negative and Gram-Positive Strains. Environ. Microbiol., 1, 307-318.

51 Shanklin, J., Whittle, E., and Fox, B.G. (1994) Eight Histidine Residues are Catalytically Essential in a Membrane-Associated Iron Enzyme, Stearoyl-CoA Desaturase, and are Conserved in Alkane Hydroxylase and Xylene Monooxygenase. Biochem., 33, 12787-12794.

52 Ratajczak, A., Geißdörfer, W., and Hillen, W. (1998) Alkane Hydroxylase from Acinetobacter sp. Strain ADP-1 is Encoded by alkM and Belongs to a New Family of Bacterial Integral-Membrane Hydrocarbon Hydroxylases. Appl. Environ. Microbiol., 64, 1175-1179.

53 Marin, M.M., Smits, T.H.M., van Beilen, J.B., and Rojo, F. (2001) The Alkane Hydroxylase Gene of Burkholderia Cepacia RR10 is Under Catabolite Repression Control. $J$. Bacteriol., 183, 4202-4209.

54 Tani, A., Ishige, T., Sakai, Y., and Kato, N. (2001) Gene Structures and Regulation of the Alkane Hydroxylase Complex in Acinetobacter sp. Strain M-1. J. Bacteriol., 183, 1819-1823.

55 van Beilen, J.B., Kingma, J., and Witholt, B. (1994) Substrate Specificity of the Alkane Hydroxylase of Pseudomonas oleovorans GPo1. Enzyme Microb. Technol., 16, 904-911.

56 Yadav, J.S., and Loper, J.C. (1999) Multiple P450alk (Cytochrome P450 Alkane Hydroxylase) Genes from the Halotolerant Yeast Debaryomyces Hansenii. Gene, 226, 139146.

57 Ohkuma, M., Zimmer, T., Iida, T., Schunck, W.H., Ohta, A., and Takagi, M. (1998) Isozyme Function of $n$-AlkaneInducible Cytochromes P450 in Candida Maltosa Revealed by Sequential Gene Disruption. J. Biol. Chem., 273, 39483953.

58 Schmitz, C., Goebel, I., Wagner, S., Vomberg, A., and Klinner, U. (2000) Competition Between $n$-AlkaneAssimilating Yeasts and Bacteria During Colonization of Sandy Soil Microcosms. Appl. Microbiol. Biotechnol., 54, 126-132.

59 Cardini, G., and Jurtshuk, P. (1970) The Enzymatic Hydroxylation of $n$-Octane by Corynebacterium sp. Strain 7E1C. J. Biol. Chem., 245, 2789-2796.

60 Müller, R., Asperger, O., and Kleber, H.P. (1989) Purification of Cytochrome P-450 from $n$-HexadecaneGrown Acinetobacter Calcoaceticus. Biomed. Biochem. Acta., 48, 243-254.

61 Munro, A.W., and Lindsay, J.G. (1996) Bacterial Cytochromes P-450. Mol. Microbiol., 20, 1115-1125.

62 Jenkins, P.G., Raboin, D., and Moran, F. (1972) Mutants of Mycobacterium Rhodochrous with Modified Patterns of n-Paraffin Utilization. J. Gen. Microbiol., 72, 395-398.

63 Van der Linden, A.C., and Van Ravenswaay Claasen, J.C. (1971) Hydrophobic Enzymes in Hydrocarbon Degradation. Lipids, 6, 437-443.

64 Azoulay, E., Chouteau, J., and Davidovics, G. (1963) Isolement et Caractérisation des enzymes responsables de l'oxydation des hydrocarbures. Biochim. Biophys. Acta, 77, 554-567.

65 Vandecasteele, J.P., Blanchet, D., Tassin, J.P., Bonamy, A. M., and Guerrillot, L. (1983) Enzymology of Alkane Degradation in Pseudomonas aeruginosa. Acta Biotechnol., 3, 339-344. 
66 Macham, L.P., and Heydeman, M.T. (1974) Pseudomonas aeruginosa Mutants Defective in Heptane Oxidation. J. Gen. Microbiol., 85, 77-84.

67 van Beilen, J.B., Veenhoff, L., and Witholt, B. (1998) Alkane Hydroxylase Systems in Pseudomonas aeruginosa Strains Able to Grow on $n$-Octane. In: New Frontiers in Screening for Microbial Biocatalysts Kieslich, K., van der Beek, C.P., de Bont, J.A.M., and van den Tweel, W.J.J. (Ed.), Elsevier Science B.V., Amsterdam.

68 Cole, S.T., Brosch, R., Parkhill, J., Garnier, T., Churcher, C., Harris, D., Gordon, S.V., Eiglmeier, K., Gas, S., Barry, C.E., III, Tekaia, F., Badcock, K., Basham, D., Brown, D., Chillingworth, T., Connor, R., Davies, R., Devlin, K., Feltwell, T., Gentles, S., Hamlin, N., Holroyd, S., Hornsby, T., Jagels, K., Krogh, A., McLeah, J., Moule, S., Murphy, L., Oliver, K., Osborne, J., Quail, M.A., Rajandream, M.A., Rogers, J., Rutter, S., Soeger, K., Skelton, J., Squares, R., Squares, S., Sulston, J.E., Taylor, K., Whitehead, S., and Barrett, B.G. (1998) Deciphering the Biology of Mycobacterium tuberculosis from the Complete Genome Sequence. Nature, 393, 537-544.

69 Andreoni, V., Bernasconi, S., Colombo, M., van Beilen, J.B., and Cavalca, L. (2000) Detection of Genes for Alkane and Naphthalene Catabolism in Rhodococcus sp. Strain 1BN. Environ. Microbiol., 2, 572-577.

70 Juni, E., and Janik, A. (1969) Transformation of Acinetobacter calcoaceticus (Bacterium Anitratum). J. Bacteriol., 98, 281-288.

71 Asperger, O., and Kleber, H.P. (1991) Metabolism of Alkanes by Acinetobacter. In: The biology of Acinetobacter Towner, K. J. (Ed.), Plenum Press, New York.

72 Fewson, C.A. (1967) The Growth and Metabolic Versatility of the Gram-Negative Bacterium NCIB 8250 ('Vibrio 01'). J. Gen. Microbiol., 46, 255-266.

73 Yakimov, M.M., Golyshin, P.N., Lang, S., Moore, E.R.B., Abraham, W.R., Lünsdorf, H., and Timmis, K.N. (1998) Alcanivorax borkumensis Gen. Nov., sp. Nov., a New, Hydrocarbon-Degrading and Surfactant-Producing Marine Bacterium. Int. J. Syst. Bacteriol., 48, 339-348.

74 Palleroni, N.J., Kunisawa, R., Contopoulou, R., and Douderoff, M. (1973) Nucleic acid Homologies in the Genus Pseudomonas. Int. J. Syst. Bacteriol., 23, 333-339.

75 Golyshin, P.N., Chernikova, T., Abraham, W.R., Luensdorf, H., Timmis, K.N., and Yakimov, M.M. (2002) Oleiphilaceae Fam. Nov., to Include Oleiphilus messinensis Gen. Nov., sp. Nov., a Novel Marine Bacterium that Obligately Utilizes Hydrocarbons. Int. J. Syst. Evol. Microbiol., 52, 901-911.

76 Vomberg, A., and Klinner, U. (2000) Distribution of alkB Genes Within $n$-Alkane-Degrading Bacteria. J. Appl. Microbiol. 89, 339-348.

77 Panicker, G., and Bej, A.K. (2001) Detection of Biodegradative Genes Using Polymerase Chain Reaction in Antarctic Isolates. Genbank Entry AAK56792.

78 Schwartz, R.D., and McCoy, C.J. (1973) Pseudomonas oleovorans Hydroxylation-Epoxidation System: Additional Strain Improvements. Appl. Microbiol., 26, 217-218.

79 Stutz, E.W., Défago, G., and Kern, H. (1986) Naturally Occuring Fluorescent Pseudomonads Involved in Suppression of Black Root Rot of Tobacco. Phytopathology, 76, 181-185.

80 Holloway, B.W. (1969) Genetics of Pseudomonas. Bacteriol. Rev., 33, 419-443.

81 Guerra-Santos, L.H., Käppeli, O., and Fiechter, A. (1986) Dependence of Pseudomonas Aeruginosa Continuous Culture Biosurfactant Production on Nutritional and Environmental Factors. Appl. Microbiol. Biotechnol., 24, 443-448.
82 Thysse, G.J.E., and van der Linden, A.C. (1958) n-Alkane Oxidation by a Pseudomonas. Studies on the Intermediate Metabolism. Anton. Leeuwenhoek, 24, 298-308.

83 Fuhs, G.W. (1961) Der mikrobielle Abbau von Kohlenwasserstoffen. Arch. Mikrobiol., 39, 374-422.

84 Lukins, H.B., and Foster, J.W. (1963) Utilization of Hydrocarbons and Hydrogen by Mycobacteria. Z. Allg. Mikrobiol., 3, 251-264.

85 Hou, C.T., Jackson, M.A., Bagby, M.O., and Becker, L.A. (1994) Microbial Oxidation of Cumene by Octane-Grown Cells. Appl. Microbiol. Biotechnol., 41, 178-182.

86 van Beilen, J.B., Smits, T.H.M., Whyte, L.G., Schorcht, S., Röthlisberger, M., Plaggemeier, T., Engesser, K.H., and Witholt, B. (2002) Alkane Hydroxylases in Gram-Positive Strains. Environ. Microbiol., 4, 676-682

87 Schorcht, S. (1998) Mikrobiologische und Molekularbiologische Charakterisierung Alkanabbauender Bakteriengemeinschaften. PhD Thesis, Universität Bremen.

88 Plaggemeier, T. (2000) Elimination der Schwer Wasserlöslichen Modellabluftinhaltsstoffe $n$-Hexan und Toluol in Biorieselbettverfahren. PhD Thesis, Universität Stuttgart.

89 Whyte, L.G., Smits, T.H.M., Labbé, D., Witholt, B., Greer, C.W., and van Beilen, J.B. (2002) Cloning and Characterization of Multiple Alkane Hydroxylase Systems in Rhodococcus spp. Strains Q15 and 16531. Appl. Environ. Microbiol., 68, 5933-5942.

90 Higgins, D.G., and Sharp, P.M. (1988) CLUSTAL: a Package for Performing Multiple Sequence Alignment on a Microcomputer. Gene, 73, 237-244.

91 Smits, T.H.M., Seeger, M.A., Witholt, B., and van Beilen, J.B. (2001) New Alkane-Responsive Expression Vectors for E. coli and Pseudomonas. Plasmid, 46, 16-24.

92 Chakrabarty, A.M., Chou, G., and Gunsalus, I.C. (1973) Genetic Regulation of Octane Dissimulation Plasmid in Pseudomonas. Proc. Natl. Acad. Sci. USA, 70, 1137-1140.

93 Asperger, O., Wirkner, K., Schmidt, M., and Flechsig, E. (1994) Detection of Diverse Cytochrome P450-Dependent Biooxygenation Catalysts in Microorganisms Using a Multipurpose Inducer. Biocatalysis, 10, 233-246.

94 Morris, S.A., Radajewski, S., Willison, T.W., and Murrell, J.C. (2002) Identification of the Functionally Active Methanotroph Population in a Peat Soil Microcosm by Stable-Isotope Probing. Appl. Environ. Microbiol., 68, 14461453.

95 Horz, H.P., Yimga, M.T., and Liesack, W. (2001) Detection of Methanotroph Diversity on Roots of Submerged Rice Plants by Molecular Retrieval of pmoA, mmoX, mxaF, and 16S rRNA and Ribosomal DNA, Including $p m o A$-Based Terminal Restriction Fragment Length Polymorphism Profiling. Appl. Environ. Microbiol., 67, 4177-4185.

96. Baker, P.W., Futamata, H., Harayama, S., and Watanabe, K. (2001) Molecular Diversity of pMMO and sMMO in a TCEContaminated Aquifer During Bioremediation. FEMS Microbiol. Ecol., 38, 161-167.

97 Sotsky, J.B., Greer, C.W., and Atlas, R.M. (1994) Frequency of Genes in Aromatic and Aliphatic Hydrocarbon Biodegradation Pathways Within Bacterial Populations from Alaskan Sediments. Can. J. Microbiol., 40, 981-985.

98 Knaebel, D.B., and Crawford, R.L. (1995) Extraction and Purification of Microbial DNA from PetroleumContaminated Soils and Detection of Low Numbers of Toluene, Octane and Pesticide Degraders by Multiplex Polymerase Chain Reaction and Southern Analysis. Mol. Ecol., 4, 579-591. 
99 Whyte, L.G., Greer, C.W., and Inniss, W.E. (1996) Assessment of the Biodegradation Potential of Psychrotrophic Microorganisms. Can. J. Microbiol., 42, 99-106.

100 Guo, C., Sun, W., Harsh, J.B., and Ogram, A. (1997) Hybridisation Analysis of Microbial DNA from Fuel OilContaminated and Noncontaminated Soil. Microb. Ecol., 34, 178-187.

101 Stapleton, R.D., and Sayler, G.S. (1998) Assessment of the Microbiological Potential for the Natural Attenuation of Petroleum Hydrocarbons in a Shallow Aquifer System. Microb. Ecol., 36, 349-361.

102 Stapleton, R.D., Sayler, G.S., Boggs, J. M., Libelo, E.L., Stauffer, T., and MacIntyre, W.G. (2000) Changes in Subsurface Catabolic Gene Frequencies During Natural Attenuation of Petroleum Hydrocarbons. Environ. Sci. Technol., 34, 1991-1999.

103 Siciliano, S.D., Fortin, N., Mihoc, A., Wisse, G., Labelle, S., Beaumier, D., Ouellette, D., Roy, R., Whyte, L.G., Banks, M.K., Schwab, P., Lee, K., and Greer, C.W. (2001) Selection of Specific Endophytic Bacterial Genotypes by Plants in Response to Soil Contamination. Appl. Environ. Microbiol., 67, 2469-2475.

104 Whyte, L.G., Schultz, A., van Beilen, J.B., Luz, A.P., Pellizari, D., Labbé, D., and Greer, C.W. (2002) Prevalence of Alkane Monooxygenase Genes in Arctic HydrocarbonContaminated and Pristine Soils. FEMS Microbiol. Ecol., 41, $141-150$.

105 Whyte, L.G., Schultz, A., van Beilen, J.B., Luz, A.P., Pellizari, D., Labbé, D., and Greer, C.W. (2002) Prevalence of Alkane Monooxygenase Genes in Arctic and Antarctic Hydrocarbon-Contaminated and Pristine Soils. FEMS Microbiol. Ecol., 41, 141-150.

106 Abbott, B.J., and Hou, C.T. (1973) Oxidation of 1-Alkenes to 1,2-Epoxyalkanes by Pseudomonas oleovorans. Appl Microbiol, 26, 86-91.

107 Van Ravenswaay Claasen, J.C., and Van der Linden, A C. (1971) Substrate Specificity of the Paraffin Hydroxylase of Pseudomonas aeruginosa. Ant. Leeuwenhoek, 37, 339-352.

108 Kiener, A. (1992) Enzymatic Oxidation of Methyl Groups on Aromatic Heterocycles: a Versatile Method for the Preparation of Heteroaromatic Carboxylic Acids. Angew. Chem. Int. Ed. Engl., 31, 774-775.

109 Johnstone, S.L., Phillips, G.T., Robertson, B.W., Watts, P.D., Bertola, M.A., Koger, H.S., and Marx, A.F. (1986) Stereoselective Synthesis of S-(-)-B-blockers via Microbially Produced Epoxide Intermediates. In: Biocatalysis in Organic Media Laane, C., Tramper, J., and Lilly, M.D. (Ed.), Elsevier, Amsterdam.
110 Li, Z., Feiten, H.J., van Beilen, J.B., Duetz, W., and Witholt, B. (1999) Preparation of Optically Active N-benzyl-3Hydroxypyrrolidine by Enzymatic Hydroxylation. Tetrahedron: Asymmetry, 10, 1323-1333.

111 Fu, H., Newcomb, M., and Wong, C.H. (1991) Pseudomonas oleovorans Monooxygenase Catalyzed Asymmetric Epoxidation of Allyl Alcohol Derivatives and Hydroxylation of a Hypersensitive Radical Probe with the Radical Ring Opening State Exceeding the Oxygen Rebound State. J. Am. Chem. Soc., 113, 5878-5880.

112 Chang, D., Witholt, B., and Li, Z. (2000) Preparation of (S)N-Substituted 4-Hydroxy-Pyrrolidine-2-Ones by Regio- and Stereoselective Hydroxylation with Sphingomonas sp. HXN200. Org. Lett., 2, 3949-3952.

113 Chang, D., Feiten, H.J., Engesser, K.H., van Beilen, J.B., Witholt, B., and Li, Z. (2002) Practical Syntheses of $N$ Substituted 3-Hydroxyazetidines and 4-Hydroxypiperidines by Hydroxylation with Sphingomonas sp. HXN-200. Org. Lett., 4, 1859-1862.

114 Clifford, K.H., Phillips, G.T., and Marx, A.F. (1988) Process for the Preparation of Substituted Phenoxy Propanoic Acids. US Patent $5037,759$.

115 Matsui, T., and Furuhashi, K. (1995) Asymmetric Oxidation of Isopropylmoieties of Aliphatic and Aromatic Hydrocarbons by Rhodococcus sp. 11B. Biosci. Biotech. Biochem., 59, 1342-1344.

116 Wilcox, D.W., Autenrieth, R.L., and Bonner, J.S. (1995) Propane-Induced Biodegradation of Vapor Phase Trichloroethylene. Biotechnol. Bioeng., 46, 333-342.

117 Dupasquier, D., Revah, S., and Auria, R. (2002) Biofiltration of Methyl Yert-Butyl Ether Vapors by Cometabolism with Pentane: Modeling and Experimental Approach. Environ. Science Technol., 36, 247-253.

118 Liu, C.Y., Speitel, G.E.J., and Georgiou, G. (2001) Kinetics of Methyl Tertiary-Butyl Ether Cometabolism at Low Concentrations by Pure Cultures of Butane-Degrading Bacteria. Appl. Environ. Microbiol., 67, 2197-2201.

119 Garnier, P.M., Auria, R., Augur, C., and Revah, S. (2000) Cometabolic Biodegradation of Methyl Tertiary-Butyl Ether by a Soil Consortium: Effect of Components Present in Gasoline. J. Gen. Appl. Microbiol., 46, 79-84.

120 Garnier, P.M., Auria, R., Augur, C., and Revah, S. (1999) Cometabolic Biodegradation of Methyl Tertiary-Butyl Ether by Pseudomonas aeruginosa Grown on Pentane. Appl. Microbiol. Biotechnol., 51, 498-503.

Final manuscript received in January 2003 